book review

\title{
Decentred
}

\section{IAN WEDDE}

\author{
Saskia Beudel \\ A Country in Mind: Memoir with Landscape \\ UWA Publishing, Perth, 2013 \\ ISBN 9781742584942 \\ RRP $\$ 29.49$
}

Like many writers, Saskia Beudel included, I need to go for walks in order to think, and therefore in order to write. I believe that walking, observing, thinking and narrating are wired into old biological networks. These days, this has become a commonplace of evolutionary psychology, and seems both theoretically and intuitively right; as well as sensible, in that this is how I feel the process working in myself. Our nomadic ancestors used to walk and talk a lot, I'm sure-entertaining each other with stories and songs, kibitzing, socialising, mapping the places and routes they traversed, naming things, commemorating events along the way, commenting on changes, teaching their children how to find their way around the place and how to get home (and maybe sometimes how to get lost). Such old (but also new) business was often, subsequently, codified in elaborate literatures, such as classical Arab poetry whose footprint is nomadic, with its mnemonics of desert trade routes, oases, campsites, and campfire stories. 
The rhythms of thoughtful language organised as spoken and written narratives are related to the rhythms of physical movement-walking most obviously, but also dancing, travelling in cars (or on camels), and typing at a keyboard, and the visual rhythms of words on pages. The rhetorics of storytelling are also physical and even material, in that they are the embodied and situated vehicles in which narratives move and by which they are articulated. There is a dumb, tum-te-tum margin to this, of course, where 'the foot' as a measure of prosody can reduce rhythmic and narrative subtlety to marching or plodding. But there are also open margins where the flâneur subverts and detournes habit, where hiphop artists improvise, where Robert Burns's 'Standard Habbie' verse-form introduces a jaunty, syncopated dance-step. More complexly, rhetorical structure expands meaning where a tauparapara (canoe-paddling chant) of Ngāti Whakaue in Rotorua, New Zealand, fluidly links and maps waterways, social relations, landmarked narratives and, indeed, the watery human bodies of paddlers in motion through place and time within the chant and the waka (canoe). Water, blood, story, and navigation circulate in and through each other. You can't tell where waka, chant and the body are distinct. Such fluid rhetorical principles ally with Epeli Hau'ofa's concept of a 'sea of islands', in which the ocean links islands rather than separates them from each other; here, Hau'ofa is both recovering Indigenous mapping of relationship, and critiquing the alienating cartographic rhetoric of European voyagers, who saw oceanic spaces as vast wastes with easy-to-sail-past pinpricks of landfall. ${ }^{1}$

There may at a stretch be room for Zygmunt Bauman's concept of 'liquid modernity' here, too, as if we are now, like Beudel, discovering modern ways of doing old imaginative work, where narrative certainty, foreclosure and structure are no longer paramount. ${ }^{2}$ Nor is it incongruous to reference liquidity in the context of this book, with its primary focus on the deserts of Australia, since the groundwater, so to speak, of its big narrative arc is water, and the ecological relationships and conflicts that water and its scarcity have produced over time. Indeed, Beudel's account begins with a kind of traumatic baptism. The opening sequence of lifethreatening passage through the freezing water of a gorge off the Larapinta Trail is also a narrow rite of passage into the expansive field of the book's main business, the desert. It's a rite of passage characterised by dread and a sense of 
transgression-I won't second-guess whether this was intended by Beudel, but it's there in her account.

And of course there are delimiting systems and cognitive technologies, whose purpose is to enclose narratives: the Claude glass; the landscape painter's repoussoir (sometimes evolutionised as a protective 'lair' perspective); the theodolite followed by its procession of survey pegs; and, among the sublime mountainscapes of New Zealand, the viewing platform designed and located to render as primeval wilderness that which is traversed by processions of creaking campervans. The weakening of the Resource Management Act (RMA) in New Zealand is symptomatic of a viewpoint shift away from ecology towards the monetising of energy-generating natural resources-not what to look at, but what to look for. Such framing devices are, of course, instrumental as well as rhetorical, as Beudel shows she knows very well. Unlike rhetorics whose effect is to open up decentered viewpoints and expansive narrative fields, the effect and indeed the purpose of delimiting rhetorical strategies is to reduce or even censor the imaginative scope of thought.

I read quite a way into Beudel's book, whose title is in effect a kind of puzzle, with a question nagging at me. It had to do with the rhetorical uncertainty of her narrative, of its viewpoint. Is this book primarily a memoir incorporating her family narrative, beginning with its troubling story of the Dutch in Indonesia under Japanese occupation? A meditation on home, and homelessness? Is it an account of her personal explorations of Australian desert country, with an underlying theme of therapeutic self-discovery? Is it primarily a broad-brush research summary of work done by anthropologists and ecologists, from which a history of Aboriginal alienation can be sifted? An advocacy essay making the case for ecological understanding of the desert and its history? A collection of exquisitely observed landscapes, both grand and miniature? An aesthetic map of country that enlarges our sense of what that might signify? A participant history of desert exploration?

I'm being only slightly disingenuous here-I had an idea of what Beudel was up to from early on. But the text's uncertainty-its shiftings of perspective, rhetorical purpose, content, and even genre-were what affected me most as a reader. There's a sense that country and its complex and chaotic inscriptions have written Beudel's text, and that this text has written her.

Then, not quite halfway through the book, I read this: 
Minoru Hokari argues that 'Gurindji cosmology is based on the networking among many sites, countries and people without a concept of "the centre"'. Because there is no 'authentic centre that guarantees the validity of information, the knowledge naturally creates many variations'. Thus different stories, which may contradict one another, 'do not conflict, but simply co-exist'. (154)

A couple of pages later, this:

As I came across and assembled these references to Indigenous narrative structures, it occurred to me that my own mode of writing, with its crossings between locations, people, and points in time, was being prompted, too, by the very place I was exploring. Perhaps my mode of composition, the seeming disconnections and reconnections, the heterogeneities, was being informed by the landscape's dynamics. (156)

Gurindji narrative, then, derives from country-its widely distributed, networked and intercut storylines. Yet Beudel's narrative, given her reflexive position in relation to Indigenous narrative, derives not just from country but also from the ways country has already been narrated, not just in accounts like those of Gurindji people but also in the anthropological, explorer, booster, ecological and literary texts that Beudel cites and quotes at length. In fact, this complex patterning of quotation and citation is another aspect of the book's 'heterogeneities'. The 'country' Beudel is exploring, sometimes driving in almost-got-lost circles, is as much textual as physical. The country is deeply inscribed, not just by the narratives of a hundred thousand years of Indigenous inhabitation, but by the proliferation of written, video and sound texts that Beudel describes herself poring over in archives and libraries; by the conversations she has at kitchen tables; and not least by the mediating presence of her daughter Olive, who grows from infancy to 'over three' in the course of the book.

Olive's small but hardly insignificant presence in the book-her reappearances in different stages of development, often being given a frugal bath with some of the book's reiterant water-is typical of a far from disconnected meshing of narrative threads throughout. Looked at in big, filmic terms, the opening sequence of terrifying entrapment in and emergence from an icy gorge is book-ended by the final emergence of Olive and her mother from another gorge, this one the nocturnal 
house of the Desert Park at Alice Springs, where the dead snake of the icy gorge reappears as a live one in captivity being fed a mouse. The dim chill of the nocturnal house, a place of undead, close-to-extinct species, is contrasted with the sight of a 'large lizard basking in a sunny sheltered spot' as Olive and Saskia emerge into the 'sharp high light of another clear desert day.' (323)

The breath-stopping chill of the opening gorge has already picked up an echo of the death of Beudel's father in the book's preface, which itself does a narrative throw to the big theme of 'place' and home: 'We waited, not knowing what to do, with no good place to go.' (xv) Of course, 'what to do' and the 'good place to go' are what the book then explores. The subtle coherence and continuity of Beudel's text don't so much work against the grain of its 'heterogeneity' as unobtrusively compose-or edit into coherence-those 'seeming disconnections and reconnections'. I think Beudel is admitting as much when she uses the word 'seeming', as if she wants both the decentred, open, underdetermined narrative, and structural shapeliness. She manages to have both, and does so gracefully without sentimental or presumptuous mimicking of what might pass for 'songlines'. I confess here to a highly prejudiced relief at not finding Bruce Chatwin referenced in the book, and an equally prejudiced disappointment at not finding Barry Hill's Broken Song there, in particular its section on translation. ${ }^{3}$ But I was both relieved and moved to find substantial references to Eric Michaels-nearly thirty years after Francis Jupurrurla Makes TV at Yuendumu, his work continues to stare down egregious bromides about what constitutes 'Aboriginality' as does the posthumous

\section{Bad Aboriginal Art. ${ }^{4}$}

Beudel's own explorations of the desertscapes are informed more often by the wonder that goes with ignorance, than by the overconfidence of expertise. There are many storylines whose apparently under-informed discontinuity is, in due course, picked up again - the story of buffel grass being a good example. Beudel describes a conversation with a friend in Alice Springs, Dave, who introduces her to buffel grass: 'I've never heard of buffel grass, and it's through Dave's passion about the subject that I begin to see the local landscape in new ways.' (210) The storyline of buffel grass spreads out like a capillary root system from this moment into the remainder of the book, reappearing as the narrative vehicle for descriptions of what it has overgrown and smothered: the fragile groundcovers of indigenous plants; the 
history of seed distribution and of acclimatisation societies; the story of the Overland Telegraph Line and the camel teams with their 'Afghan' cameleers; the boosters of pastoralism and the ecological disasters of overgrazing; the grass's damaging relationship to desert fire ecology. Towards the end of these 'disconnections and reconnections', Beudel is able to come to a modest but comprehensive conclusion, one that is both particular and metonymic:

So through my days spent in Alice Springs libraries it was possible to trace in this one exotic grass broader patterns of human desire in the desert landscape: desire for wealth, desire to settle more extensively and comprehensively across the colonised landscape, desire to overcome the perceived limitations of the arid lands, with little comprehension of where those 'improvements' might lead and what unforeseen consequences may result. (251)

Typically, however, she doesn't let the matter rest there, on a solemn admonishing note. An old friend, Ian, arrives unexpectedly (as if walking the talk of the book's rhetorical surprisingness) at Beudel's mother's house in Melbourne, where she and Olive are staying while she does research in Museum Victoria, looking at photographs by the biologist and anthropologist Donald Thomson. Ian has a folio of drawings of buffel grass.

He'd brought some of his recent botanical illustrations to show my mother, in one of those small coincidences or serendipities that occur once you're absorbed in a subject or object, or theme. Suddenly it starts appearing everywhere, in unexpected places and guises. 'I've just finished this,' he said. 'The spikelets and upper flower of buffel grass are extraordinarily beautiful.' He laid his drawing on the table. We bent over his finely drawn illustration, and in that moment buffel grass transformed into an aesthetic object. (258)

I'm struck by Beudel's phrase, 'absorbed in a subject or object, or theme'. Its careful distinctions imply the possibility that these categories may get mixed up-as they usually do with aesthetic experience. At this point I could reverse-spool the narrative thread of the aesthetic back through Beudel's text, and bring into view a rich sequence of diverse instances of the aesthetic's shell-game, its tricky shuffling of 'subject or object' from her own descriptions of landscape, to accounts of her 
father's photographs, to a discussion of the aesthetics of Aboriginal knowledge of country, to the visual structure of Francis Jupurrula's video, to her mother's Sunday painter work, to the paintings of Albert Namatjira, and more. Unobtrusively, in this final appearance of buffel grass, the significance of its aesthetic value is inseparable from the beauty of knowledge about it, including its shapeshifter, destructive capacity. The ambiguity we're left with is at once delicate and disturbing as two stories are permitted to coexist-one about threatening 'unforseen consequences', the other about beauty-without any final editorial judgment repressing the tension between them.

I've long admired the complex, conflicted literature of country that the Australian situation has generated, if not the history as such. Beudel's book is a fine addition to that engaged discourse. Where I am now in Berlin I can't reach for the books that are on my shelves back in Auckland. Many are in Beudel's bibliography and many have been in conversation with writers in New Zealand. I think in particular of my friend the late Geoff Park's citations of Deborah Bird Rose. ${ }^{5}$ Geoff's work was increasingly informed by the Māori concept of 'whenua', in which place, home, natural world, and human placenta are inseparable. The way the word 'country' has come to be used in Australia resonates with this.

I went walking to think about Saskia Beudel's book in Treptower Park here in Berlin, where the river Spree was frozen over and people were exercising their dogs in the snow among bare deciduous trees. I may have been distant from the minds and locations in her book, and spectacularly remote from the landscape she describes so well, but I didn't feel so. The loosely coupled narratives Beudel weaves into shapely thought could be deployed as a conceptual template where I amthough of course her lovely attentions to the particular and local would be missing. Here, as anywhere, it's not possible to walk around the place without being conscious of an incessant muttering. It comes up out of place, out of country, out of whenua-for example from the little brass plaques embedded in Berlin's pavements, which mark buildings from which Jews were taken by the Nazis.

The park where I was walking and thinking about Beudel's book was bare and pale, the snow marked sporadically by footprints; but it was also dense and garrulous with confluences of human activity and natural forces, the city there because the ancient trade conduit of the river was. And the park, a palimpsest of the 
natural and the artefactual, was full of the stories that people were repeating in chilly puffs of breath as they walked along together, laughing and bickering. They were mostly speaking the fast, sing-songy, slang-rich German of Berliners, not the Plattdüütsch of my Baltic ancestors, but I felt uncertainly connected within a network whose spatial and temporal coordinates were occasionally, unpredictably, clear and present. At such moments, I wasn't thinking about Saskia Beudel's book as an object; it was sympathetically present as a method or practice, a supple bridge between subject and object, and a subtle drawing-together of the thematic terms in her book's puzzling title: 'country', 'mind', 'memoir', 'landscape'. Beautiful.

Ian Wedde is a New Zealand poet, novelist and essayist currently living in Berlin. He has written frequently about the geomentalities of landscape, most obviously in his 2006 novel The Viewing Platform, a satire of institutionalised tourism slogans such as ' $100 \%$ Pure'.

\footnotetext{
-NOTES

${ }^{1}$ Epeli Hau'ofa, 'Our Sea of Islands', and 'The Ocean in Us', in We Are the Ocean: Selected Works, University of Hawai'i Press, Honolulu, 2008.

2 Zygmunt Bauman, Liquid Times: Living in an Age of Uncertainty, Polity Press, Cambridge/Malden, MA, 2007.

${ }^{3}$ Bruce Chatwin, The Songlines, Franklin Press, Franklin Centre, PA, 1986; Barry Hill, Broken Song: T.G.H. Strehlow and Aboriginal Possession, Knopf, Sydney, 2002.

${ }^{4}$ Eric Michaels, For a Cultural Future: Francis Jupurrurla Makes TV at Yuendumu, Art and Criticism Monograph Series, vol. 3, Artspace, 1987; and Bad Aboriginal Art: Tradition, Media, and Technological Horizons, University of Minnesota Press, Minneapolis, 1994.

${ }^{5}$ Geoff Park, Theatre Country: Essays on Landscape and Whenua, Victoria University Press, Wellington, 2006; and see also Nga Uruora: The Groves of Life: Ecology \& History in a New Zealand Landscape, Victoria University Press, Wellington, 1995.
} 